\title{
Calcination of Dredged Sediments : Investigation of the Behaviour of Heavy Metals and the Organic Compounds.
}

\author{
Jocelyn Ramaroson ${ }^{1,}$, Jean-Louis Dirion', Ange Nzihou ${ }^{1}$, Patrick Sharrock ${ }^{2}$ and Guy Depelsenaire ${ }^{3}$ \\ 1- Ecole des Mines d'Albi-Carmaux, RAPSODEE UMR-CNRS 2392, Route de Teillet-81013 \\ 'ALBI CT Cedex 09, France \\ 2- IUT, de Castres, Universite Paul Sabatier, Avenue Georges Pompidou, BP 258, 81104 CASTRES, France \\ 3- Direction Centrale de la Recherche Technologique SOLVAY SA, rue de Ransbeek 310, B-1120 Bruxelles \\ Belgique
}

(Received December 20,2008)

\begin{abstract}
The deposit of sediment causes the silting of channels, rivers and lakes. This completely natural phenomenon is exacerbated by the introduction of industrial and urban wastes into the erosion and sedimentation process. Consecutively, other problems appear, such as flooding risks, decrease of biological purification capacity and associated loss of the biodiversity. The presence of toxic compounds (from industrial, household or agricultural origins) in the sediments worsens the situation, and requires curing to restore the natural environment and its function. This study assesses the technology to treat heavy metals from dredged sediments using phosphoric acid (The Novoso ${ }^{\circledR}$ process, developed by Solvay) with the goal of converting metals, mainly $\mathrm{Pb}, \mathrm{Cd}, \mathrm{Zn}$ and $\mathrm{Cu}$ to insoluble metallic phosphates, and engineering properties (by calcination) of the final residues for the beneficial use. The effectiveness of the treatment was evaluated by performing the chemical reaction, followed by convective drying and maturation of the treated sediment at ambient temperature and finally calcination $\left(400^{\circ} \mathrm{C}-1000^{\circ} \mathrm{C}\right)$. This paper is focused on the investigation of the behaviour of the heavy metals
\end{abstract}

and organic compounds during calcination of the phosphated dredged sediment. Afterwards, the structural change of the sediment during thermal treatment was investigated: particle size, specific surface area, density and the porosity changes of the treated sediment in relation with the vaporization of heavy metals.

\section{INTRODUCTION}

Over the last century, degradation of harbours has resulted from extensive contamination of the associated sediments. The maintenance of waterways is of great concern in the USA as well as in European countries, as there is at present no satisfactory solution to the management of dredged sediments. The case of sediments is of particular interest, since large amounts of sediments are dredged to maintain harbour installations and keep rivers navigable. When the dredged zone is located near industrial, urban, or specialized sites, these sediments are in most cases polluted by heavy metals and organic compounds such as PAHs /1-3/ and dioxins /4/, that are harmful to the environment and may also be a threat to human health at high concentrations. Depending on their metal toxicity

\footnotetext{
"Corresponding author: Jocelyn.ramaroson@mines-albi.fr, Tel: +33563493240, Fax: +33563493099
} 
they will be either spread on agricultural land, confined or sent for chemical treatment $/ 5 /$. In many cases, their spreading on land is consequently no longer possible for obvious safety reasons.

Consequently dredging of this material for channel maintenance and expansion presents a potentially enormous cost due to its removal, treatment, and ultimate disposal. Therefore, stabilizing metal pollutants and destroying organics from these sediments for either the beneficial reuse or safe storage is a very attractive option. There is growing interest in stabilizing metals and destroying organic pollutants in these sediments and using them for the production of secondary materials. A technology to accomplish this objective is the treatment of raw dredged sediments with soluble phosphates followed by calcination, where the product has potential application in roadway pavements, concrete, and brick fabrication, as well as other potential applications. Solvay (a Belgian international company) has developed such a technology (the NOVOSOL ${ }^{\circledR}$ process) $/ 6 /$ to immobilize metal contaminants into hydroxyapatite $\left(\mathrm{M}_{5}\left(\mathrm{PO}_{4}\right)_{3} \mathrm{OH}, \mathrm{M}\right.$ : divalent metal) and decomposed organic pollutants; this treatment process has been optimized for numerous fly ashes, automobile shredder residues, and dredged sediments contaminated with both inorganic and organic contaminants throughout Europe. Incorporation of wastes into construction materials is a new field that is growing in many countries.

The potential utilization of the Treated Sediments as a base for the fabrication of construction materials, for rehabilitation of quarries, the building of waterway banks and paths, and fabrication of bricks, is being demonstrated, as well as the eco-compatibility of the final product in its final application. Experimental projects dealing with these issues are in progress in France, Italy and Belgium.

The current practice used for the management of contaminated dredged sediments is to store them in controlled watertight lagoons, but this is more and more restricted because of the associated effects on landscape, odor emissions, and because it does not address the risk that the polluted sediments pose in the long-term. Plants growing on the stored deposits have been tested for their potential to take up the pollutants, but here again it is not a pollution remediation but only a possible pollution transfer.

The objective of the technology is to immobilize heavy metals in sediments as a stable, low solubility, metal-phosphate complex and then, if desirable, calcinate the sediments to produce usable materials with interesting physical properties (density, surface area, particle size) and destroy toxic organics.

The process consists of three successive stages: chemical treatment with phosphoric acid ( $3 \% \mathrm{wt}$ ), drying and maturation at room temperature, and a final thermal treatment between 400 and $900^{\circ} \mathrm{C}$. The first stage is a liquid-solid reaction during which the sediment is brought into contact with a liquid reagent (phosphate). The objective of this step is the immobilization of heavy metals $(\mathrm{Pb}, \mathrm{Zn}, \mathrm{Cu}, \mathrm{Co})$ and metalloids (As) in the form of insoluble metal phosphate precursors. These created phosphates are insoluble in a large range of $\mathrm{pH}$ and this represents a large improvement in comparison to hydroxides or salts metallic forms. The resulting chemical transformation creates a new phosphate compound in which the heavy metals are trapped as described in the simplified example below:

$$
\begin{array}{r}
10 \mathrm{~Pb}^{2+}+6 \mathrm{H}_{2} \mathrm{PO}_{4}+2 \mathrm{H}_{2} \mathrm{O} \underset{\text { precipitation }}{\longrightarrow} \\
\qquad \mathrm{Pb}_{10}\left(\mathrm{PO}_{4}\right)_{6}(\mathrm{OH})_{2}+14 \mathrm{H}^{+}
\end{array}
$$

The second stage, drying and maturation of the sediment under ambient conditions of temperature and moisture, allows a decrease in the moisture. This is explained by progressive evaporation (caused by gas emission) of the moisture and maturation of the reaction products by continuation of the phosphoric acid neutralization and extending the stability of the final residues and structural changes.

The third stage (which is optional depending on the final use of the sediments and the presence of organic pollutants) is calcination of the treated sediments at a temperature high enough to transform the metal phosphate precursors into still more inert crystalline compounds such as hydroxypyromorphite, $\mathrm{Pb}_{5}\left(\mathrm{PO}_{4}\right)_{3} \mathrm{OH}$ or Morelandite, $(\mathrm{Ba}, \mathrm{Ca}, \mathrm{Pb})_{5}\left(\mathrm{AsO}_{4}, \mathrm{PO}_{4}\right)_{3} \mathrm{Cl}$. In addition, during this step organic matter is eliminated by combustion and the final product is purely mineral in composition. 
The latter stage is related to the sintering process that led to the porosity reduction, specific surface area reduction, particle size growth. This consequently reduces the environmental availability of the entrapped pollutants as confirmed by leaching tests performed when assessing the environmental impact $/ 7 /$.

This paper is focused on the investigation of the behaviour of the heavy metals and organic compounds during calcination of the phosphated dredged. Afterwards, the structural change of the sediment during thermal treatment was investigated: particle size, specific surface area, density and the porosity changes of the treated sediment. The understanding of the evolution on these properties will help for the beneficial reuse of the treated sediment in various industry such as the civil engineering.

\section{MATERIALS AND METHODS}

\subsection{Preparation of sample}

The experiments were conducted with sediments from two different regions named sediment SV and SD. The samples used for the calcination were treated with phosphates in the NOVOSOL ${ }^{\circledR}$ pilot unit located at Dombasles-sur-meurthe (France). The choice in sediments has been made relating to the industrial past of both regions. After collecting, sediments were stored in closed plastic containers at $4^{\circ} \mathrm{C}$ to reduce bacterial activity that could change their physical and chemical properties. In order to determine these characteristics, the French standard AFNOR /8/ NF X 31-101 has been used. It consist of drying the sediment at $40^{\circ} \mathrm{C}$ until total evaporation of the water content and stabilization of its mass, then on grinding and sieving at $2 \mathrm{~mm}$.

\subsection{Calcination procedure}

The sediment is introduced into an alumina crucible for a thermal treatment in a static furnace. The heating rate of $10^{\circ} \mathrm{C} / \mathrm{min}$ was imposed from room temperature to the designated isotherm temperatures for the experiments (from 100 to $1000^{\circ} \mathrm{C}$ ). This temperature is maintained during $3 \mathrm{~h}$, after which it decreases until ambient temperature.

\subsection{Chemical characterization}

The moisture, heavy metal and organic contents of the two sediments are presented in this section. The moisture was determined by drying the samples at $105^{\circ} \mathrm{C}$ during 3 days. The metal concentration was determined according to the total digestion as proposed in the NFX 31151 French standard /8/ followed by the dissolution of the solid with $100 \mathrm{ml}$ of distilled water and the analysis with the ICP-AES to determinate the metal concentration.

After removing calcium carbonate with $\mathrm{HCl}$ in a Thermo NA 2001 CHNS analyzer, the total organic matter rate was determined using the French NF X31409 Standard $/ 8 \%$. The chemical characteristics obtained are presented in Table $\mathrm{la}$ and $\mathrm{Ib}$.

Table 1a

Initial chemical characteristics of the sediments

\begin{tabular}{|l|c|c|c|c|c|}
\hline Sample & $\begin{array}{c}\% \\
\text { moisture }\end{array}$ & $\mathrm{pH}$ & $\% \mathrm{C}_{\text {Total }}$ & $\% \mathrm{C}_{\text {Org }}$ & $\% \mathrm{C}_{\text {Inorg }}$ \\
\hline $\begin{array}{l}\text { Sediment } \\
\text { SV }\end{array}$ & 34,4 & 5,7 & 4,5 & 3 & 1,5 \\
\hline $\begin{array}{l}\text { Sediment } \\
\text { SD }\end{array}$ & 34,4 & 5,9 & 17,5 & 11,7 & 5,8 \\
\hline
\end{tabular}

Table Ib

$\mathrm{Ca}, \mathrm{P}$ and Metal content (mg/kg) (dry)

\begin{tabular}{|l|l|l|l|l|l|l|}
\hline Sample & $\mathrm{P}$ & $\mathrm{Ca}$ & $\mathrm{As}$ & $\mathrm{Cd}$ & $\mathrm{Pb}$ & $\mathrm{Zn}$ \\
\hline $\begin{array}{l}\text { Sediment } \\
\text { SV(mg/kg) }\end{array}$ & 9269 & 14584 & 189,3 & 15,3 & 823 & 2532 \\
\hline $\begin{array}{l}\text { Sediment } \\
\text { SD(mg/kg) }\end{array}$ & 4539 & 52987 & 278 & 38 & 1143 & 5438 \\
\hline
\end{tabular}

\subsection{Characterization of heavy metal in gaseous phase}

The calcination experiments were carried in a preheated horizontal tubular furnace CARBOLITE $12 / 65 / 600$ (diameter $=60 \mathrm{~mm}$, length $=600 \mathrm{~mm}$ ) when we introduced $10 \mathrm{~g}$ of sediment into an alumina crucible. During the calcination experiments, the air flow rate was fixed at $150 \mathrm{~L} / \mathrm{h}$ and the temperature at 500 to 
$1000^{\circ} \mathrm{C}$. The composition of the matrix containing heavy metals on the vaporization of metals was studied. Finally, the oven was connected to two impingers filled with a solution of $100 \mathrm{~mL} \mathrm{HNO}_{3} 0.5 \mathrm{M}$ allowing the collection of the vaporized fraction of the heavy metals to be determined (Fig. 1).

\subsection{Physical characterization}

The specific surface area of the samples was determined using nitrogen adsorption with BET method (MICROMETRICS Gemini Vacprep 061). The solid density of the HAP was determined by helium pycnometry (MICROMETRICS, Accupyc 1330). The particle-size distribution was determined using a MASTERSIZER 2000-HYDRO 2000 of MALVERN INSTRUMENTS analyzer. The true density was measured by a helium pycnometer (ACCUPYC 1330 of MICROMERITICS). The cell used is that of $10 \mathrm{~cm}^{3}$.

$\mathrm{X}$-ray diffraction measurements (XRD) were carried out with $\mathrm{CuK}_{\alpha}$ radiation generated at $40 \mathrm{~mA}, 3^{\circ}<2 \theta<$ $60^{\circ}$ range and at a scanning speed of $2 \% \mathrm{~min}$. The phases present were determined by comparing the patterns with the JCPDS standards. The surface characteristics of the sediments (microstructure) were studied using environmental scanning electron microscopy (XL 30 ESEM-FEG, Phillips). The initial physical characteristics of the two sediments are presented in Table 2. Results obtained show that the sediment is mainly composed of silica, clay, feldspath and calcite.

Table 2

Characteristics of the sediments

\begin{tabular}{|l|c|c|c|}
\hline Sample & $\begin{array}{c}\text { Density } \\
\left(\mathrm{kg} / \mathrm{m}^{3}\right)\end{array}$ & $\begin{array}{c}\text { Size } \\
\text { Distribution } \\
\mathrm{D}_{50}(\mu \mathrm{m})\end{array}$ & $\mathrm{Sp}\left(\mathrm{m}^{2} / \mathrm{g}\right)$ \\
\hline $\begin{array}{l}\text { Sediment } \\
\text { SV }\end{array}$ & 2,45 & 28 & 10,1 \\
\hline $\begin{array}{l}\text { Sediment } \\
\text { SD }\end{array}$ & 2,45 & 28,6 & 10,6 \\
\hline
\end{tabular}

\subsection{Thermal characterization}

Differential scanning calorimetry (DSC) and thermogravimetry (ATG) were conducted simultaneously using a NETZSCH STA 409 PC instrument. These samples were heated from room temperature to $1000^{\circ} \mathrm{C}$ at $10^{\circ} \mathrm{C} / \mathrm{mn}$ under Argon atmosphere.

The densification (linear shrinkage) of sediments was determined by thermomechanical analyzer, TMA (TMA SETARAM SETSYS 16/18) on cylindrical samples. The samples were heated up to the temperature of $1000^{\circ} \mathrm{C}$ at a heating rate of $10^{\circ} \mathrm{C} / \mathrm{mn}$. The ESEM micrographs when combined with the mass loss (TGA) and the TMA can provide excellent insight to the sintering process.

\section{RESULTS AND DISCUSSION}

\section{1 Behaviour of the organic compounds and heavy metals}

The calcination of the phosphated dredged sediments has been carried out from room temperature to $1000^{\circ} \mathrm{C}$. The most significant effect observed is the destruction of organics (Figure 1). The TGA curves show the total destruction of organics at $700^{\circ} \mathrm{C}$. This result is similar to that published by Hu et al $/ 9 \%$.

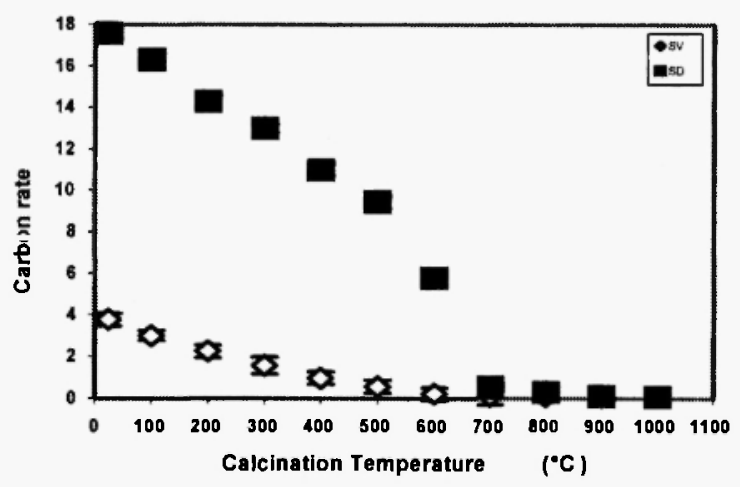

Fig. 1: Total carbon rate for the sediments SV and SD

The distribution of heavy metals of sediment SV and SD between the solid phase and the gas phase was studied during the calcination. The results (Figure 2a and Figure 2b) obtained showed that the majority of heavy metals are trapped in the solid. Generally, two behaviors can be noticed according to the temperature: 
between $500^{\circ} \mathrm{C}$ to $700^{\circ} \mathrm{C}$, the concentration of heavy metal increase only $2 \%$ compared to the initial concentration, and after $800^{\circ} \mathrm{C}$, we note a constant vaporization. This vaporization is important for $\mathrm{Cd}$ and $\mathrm{Pb}$, while that for $\mathrm{Zn}$ and for As is negligible.

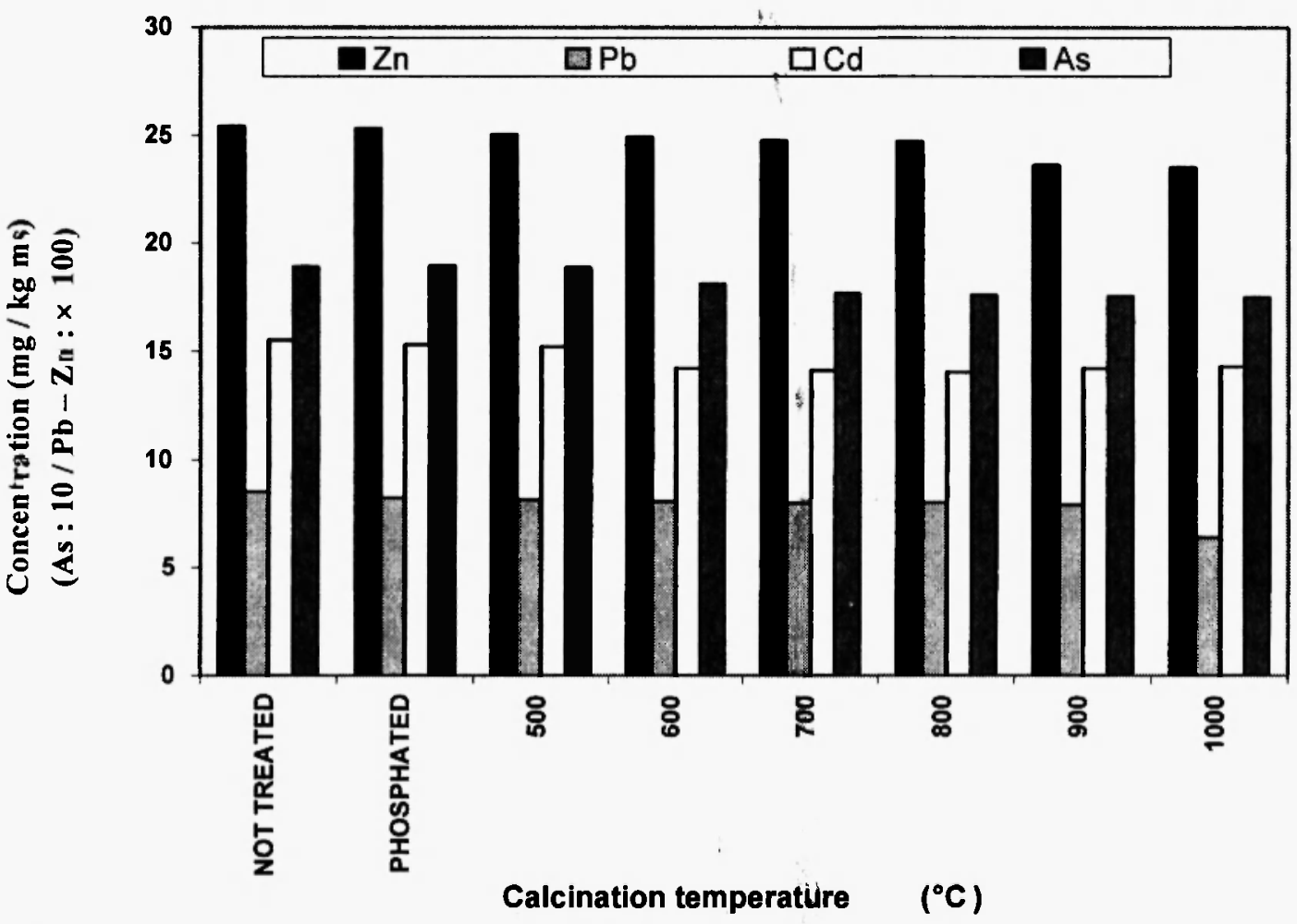

Fig. 2a: Concentrations of heavy metals for sediments SV in the solid matrix versus calcination temperature

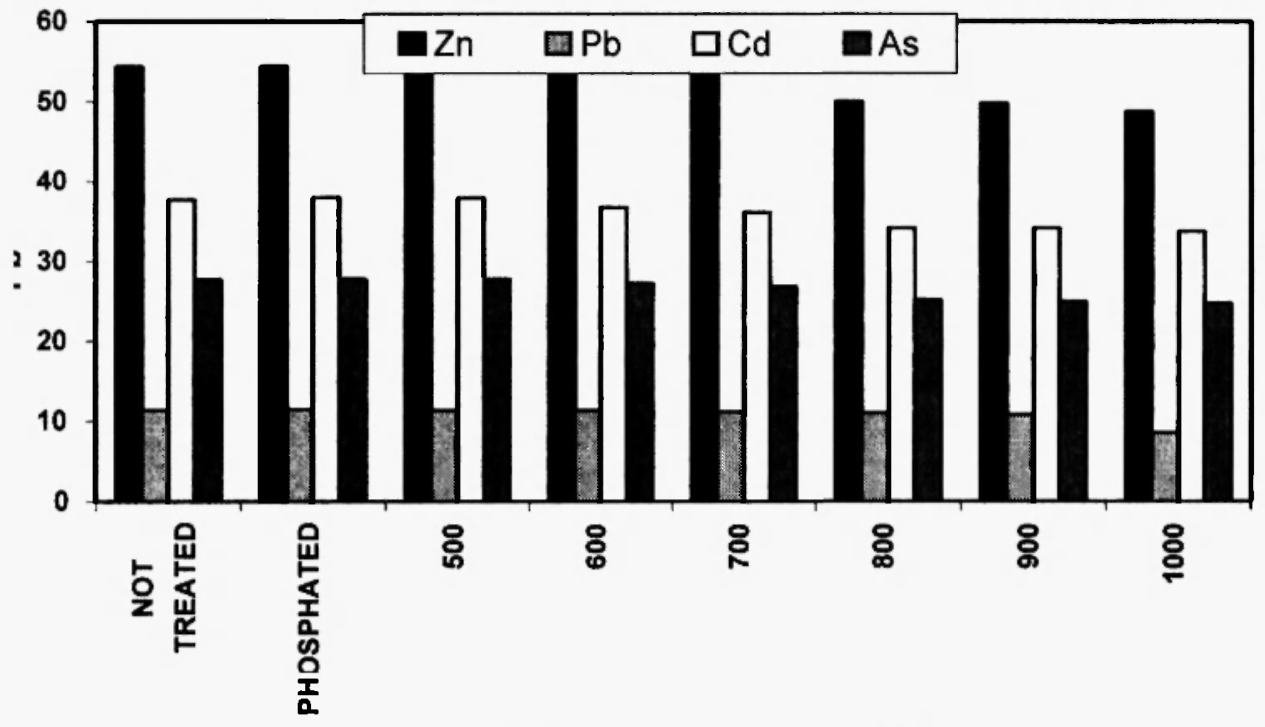

Calcination temperature $\quad\left({ }^{\circ} \mathrm{C}\right)$

Fig. 2b: Concentrations of heavy metals for sediments SD in the solid matrix versus calcination temperature 
For a better understanding of the distributions of heavy metals between the solid and gas, we represented the ration solid concentration / gas concentration for $\mathrm{Zn}$, $\mathrm{Pb}, \mathrm{Cd}$ and As for sediment SV and SD (Figure $3 \mathrm{a}$ and Figure 3b).

The results presented show a low concentration of $\mathrm{Zn}, \mathrm{Pb}, \mathrm{Cd}$ and $\mathrm{As}$ in gas phase (around from 6 to $7 \% \mathrm{wt}$ ). The majority of these metals is probably condensed. Condensation is well-known and have been described for incineration of waste. It has been shown that about 30 to $40 \%$ (wt) of the total quantity of metals condense in the de-dusting system. In our case, the low air flow circulation together with the temperature gradient are favorable conditions for the condensation. To evaluate the stabilization of these metals, TPLC (Toxicity Charactrestic Leaching Procedure) test was used. According to the results (Table $3 \mathrm{a}$ and Table $3 \mathrm{~b}$ ), it can be observed that the concentrations of analyzed heavy metals are very low in comparison to that for phosphated sediments (not calcined). This means that the calcination improves the stability and the immobilization of heavy metals.

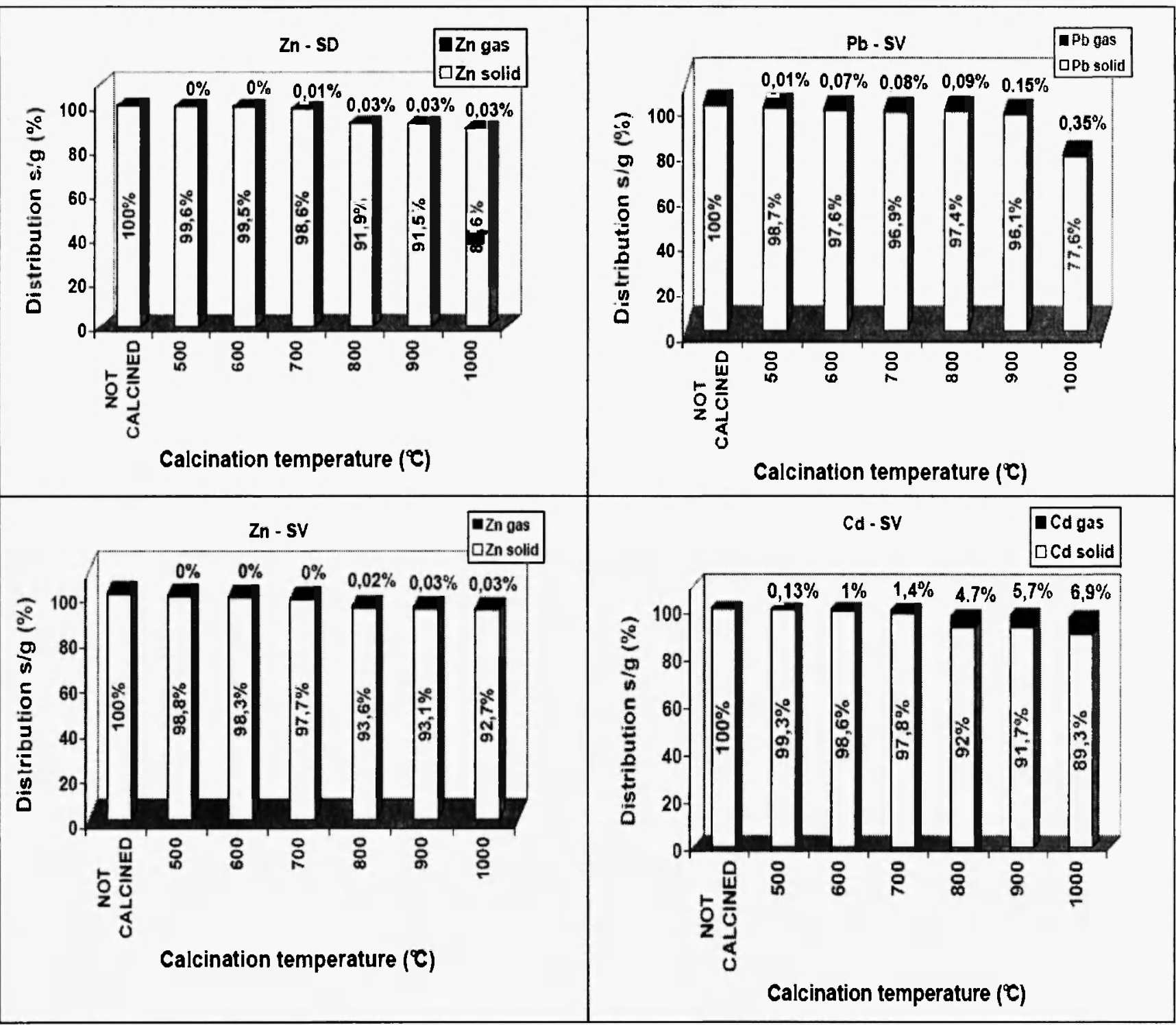




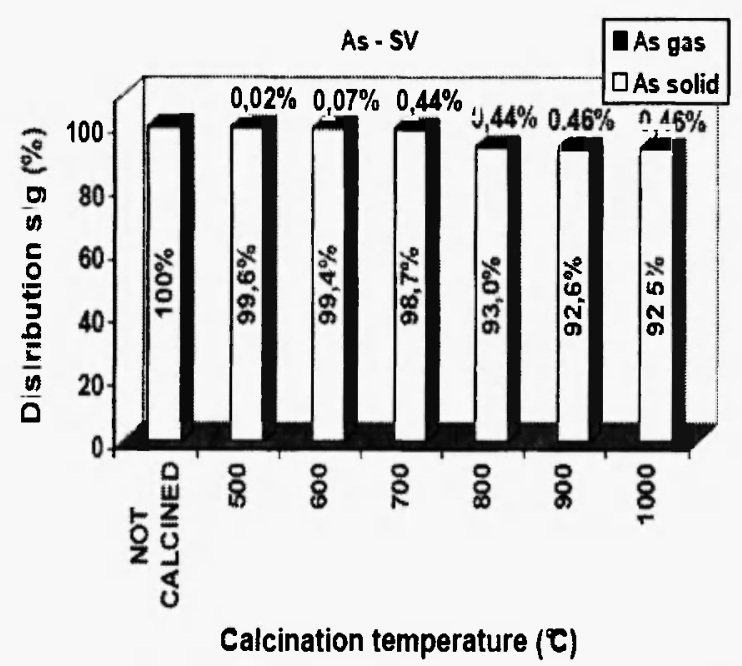

Fig. 3a: Distribution of $\mathrm{Zn}, \mathrm{Pb}, \mathrm{As}, \mathrm{Cd}$ between solid and gas phases versus calcination temperature for sediment SV

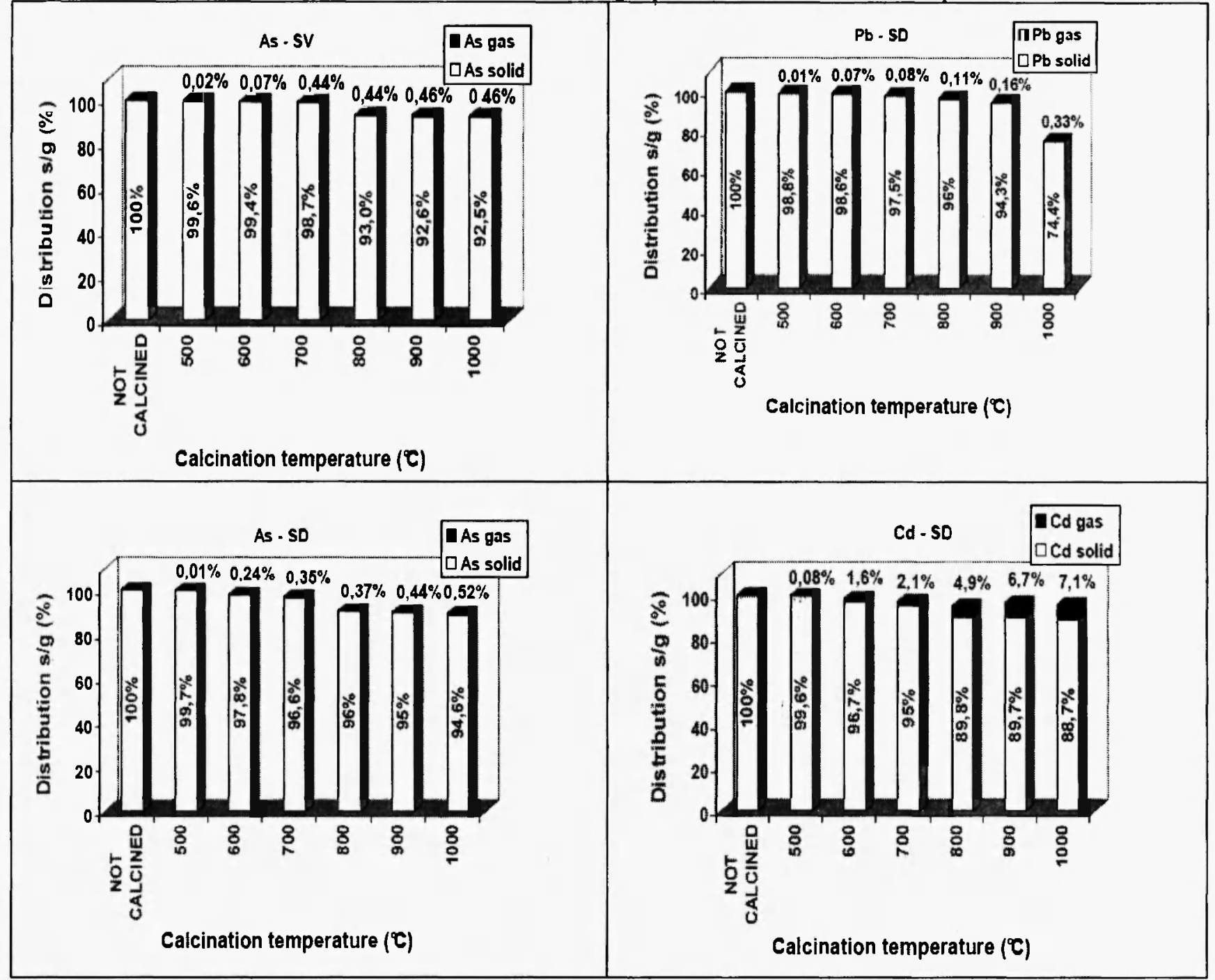

Fig. 3b: Distribution of $\mathrm{Zn}, \mathrm{Pb}, \mathrm{As}, \mathrm{Cd}$ between solid and gas phases versus calcination temperature for sediment $\mathrm{SD}$ 
Table 3a

TPLC (Toxicity Charactrestic Leaching Procedure) test for calcined sediment SV $(\mathrm{mg} / \mathrm{l})$

\begin{tabular}{|l|c|c|c|c|}
\hline $\begin{array}{c}\text { Temperature } \\
\left({ }^{\circ} \mathrm{C}\right)\end{array}$ & $\mathrm{Zn}$ & $\mathrm{Pb}$ & $\mathrm{Cd}$ & $\mathrm{As}$ \\
\hline Not calcined & 0,21 & 0,01 & 0,01 & 0,06 \\
\hline 500 & 0,01 & 0,01 & 0 & 0,06 \\
\hline 600 & 0,02 & 0,01 & 0 & 0,06 \\
\hline 700 & 0,02 & 0,02 & 0 & 0,06 \\
\hline 800 & 0,03 & 0,01 & 0 & 0,07 \\
\hline 900 & 0,03 & 0,01 & 0 & 0,07 \\
\hline 1000 & 0,03 & 0,01 & 0 & 0,08 \\
\hline $\begin{array}{l}\text { Detection } \\
\text { limit (mg/l) }\end{array}$ & 4 & 0,5 & 0,04 & 0,5 \\
\hline
\end{tabular}

Table 3b

TPLC (Toxicity Charactrestic Leaching Procedure) test for calcined sediment SD (mg/l)

\begin{tabular}{|l|c|c|c|c|}
\hline $\begin{array}{l}\text { Temperature } \\
\left({ }^{\circ} \mathrm{C}\right)\end{array}$ & $\mathrm{Zn}$ & $\mathrm{Pb}$ & $\mathrm{Cd}$ & $\mathrm{As}$ \\
\hline Not calcined & 3,22 & 0,11 & 0,03 & 0,23 \\
\hline 500 & 0,14 & 0,01 & 0 & 0,01 \\
\hline 600 & 0,62 & 0,01 & 0 & 0,01 \\
\hline 700 & 0,78 & 0,01 & 0 & 0,02 \\
\hline 800 & 0,43 & 0,01 & 0 & 0,02 \\
\hline 900 & 0,62 & 0,02 & 0 & 0,02 \\
\hline 1000 & 0,4 & 0,01 & 0 & 0,02 \\
\hline $\begin{array}{l}\text { Detection } \\
\text { limit }\end{array}$ & & & & \\
\hline (mg/l & 4 & 0,5 & 0,04 & 0, \\
\hline
\end{tabular}

\subsection{Structural changes}

The trend observed could be explained by the decomposition of organics that results in the evaporation of $\mathrm{CO}_{2}$ and water vapour generating the creation of porosity in the sediment. The consequence of such a phenomenon is the significant increase of the specific surface area that reaches the maximum at $400^{\circ} \mathrm{C}$ (Figure 4) for both sediments. The increase in the surface area is higher in the case of the SV according to the higher initial organic content (see Table 1).
After $400^{\circ} \mathrm{C}$, the results presented in Figure 4 show a significant decrease of the surface area. It can be noticed that the decrease in surface is linked with the growth of sediment particles size as shown in Figure 5.

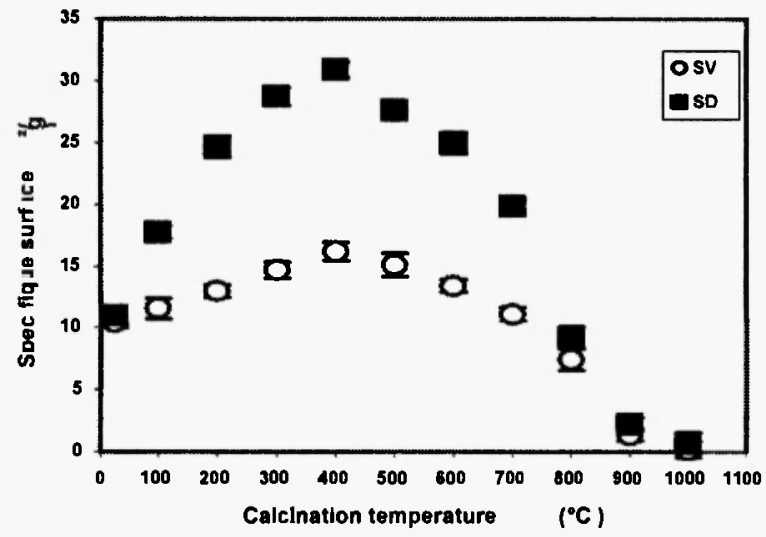

Fig. 4: Specific surface area versus calcinations temperature

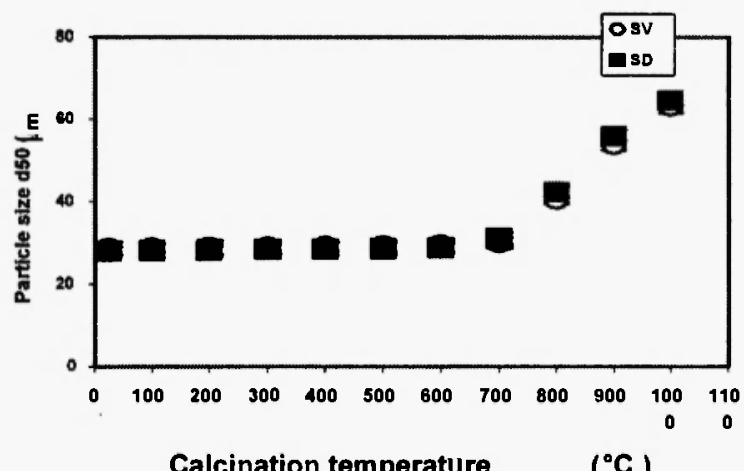

Fig. 5: Particle size growth with the calcinations temperature

These results could be explained by the sintering of phosphated mineral matrices well known in the literature at temperatures higher then $600^{\circ} \mathrm{C} / 10-12 \%$. Sintering occurs in three stages as described by White /13/. In the initial stage, the areas of contact between adjacent particles form and grow. In the intermediate stage, growing necks merge and the large number of small particles are replaced by a smaller number of large particles. This stage produces interparticle porosity whose surface may be inaccessible both to reactant gas during the reaction and to the nitrogen used 
to measure the specific surface area. In the final stage of sintering, the pore spaces become broken up with isolated closed pores remaining which shrink in size as densification proceeds $/ 13 /$. Hence the sintering process is due to volumetric shrinkage at a constant mass as it can be observed in TMA analysis of the sediments presented in Figure 4.

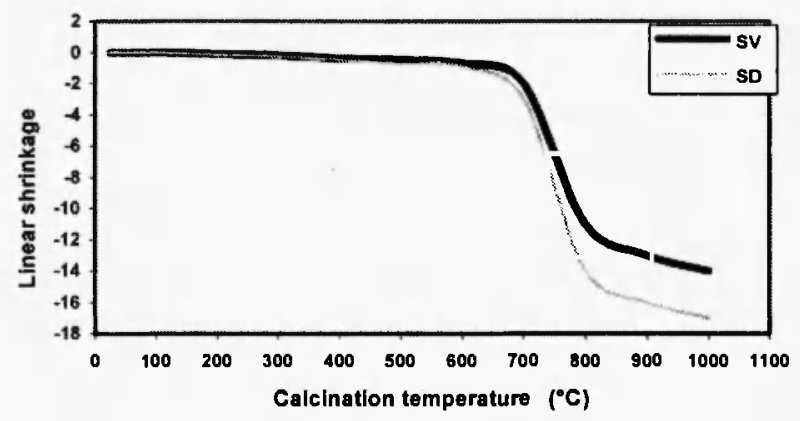

Fig. 6: Plots of shrinkage (\%) for the calcined sediments

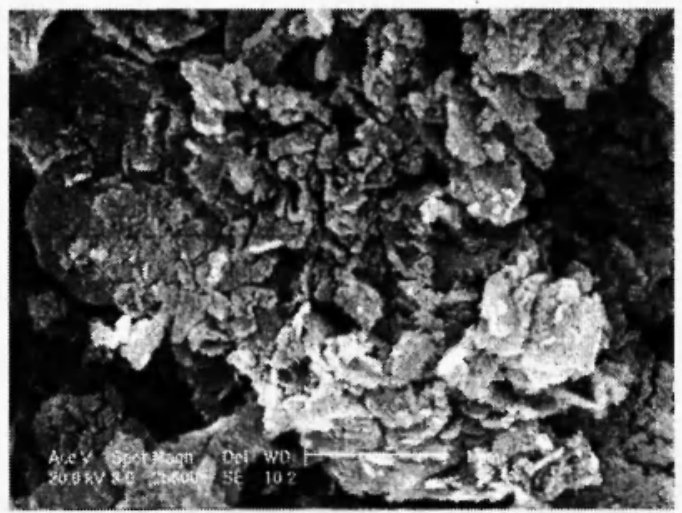

Before calcination

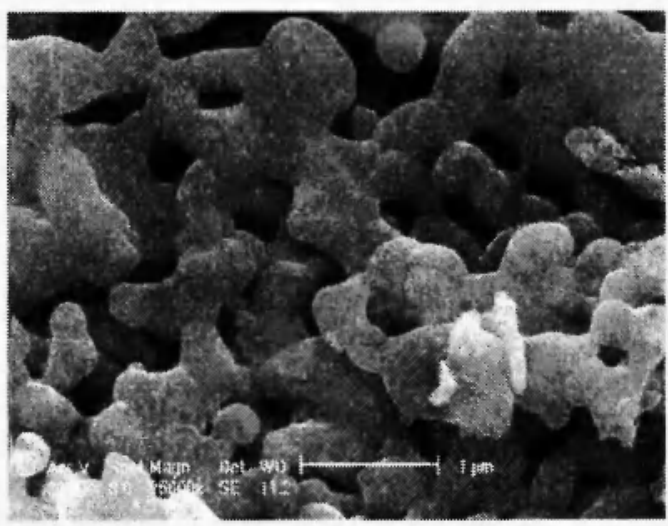

Advanced stage of sintering $\left(800^{\circ} \mathrm{C}\right)$
The shrinkage begins at $650^{\circ} \mathrm{C}$ and continues up to the temperature studied $\left(1000^{\circ} \mathrm{C}\right)$ achieving $14 \%$ shrinkage for SV and $17 \%$ for SD. This fact is also manifested in environmental scanning electron microscope (ESEM) micrographs shown in Figure 6. The surface of the particles is not much compacted at room temperature. The surface appears to be compacted to some extent at $700^{\circ} \mathrm{C}$ while it is highly compacted and fused at $1000^{\circ} \mathrm{C}$. Only the results obtained for the sediment SV are presented since a similar observation was made with the sediment SD. The ESEM results corroborate well with Figures 2, 3 and 4, showing the intensification of the sintering with the increase of the temperature. The rate of densification (rate of shrinkage not presented in the paper) reveals that the maximum shrinkage occurs at $1200^{\circ} \mathrm{C}$

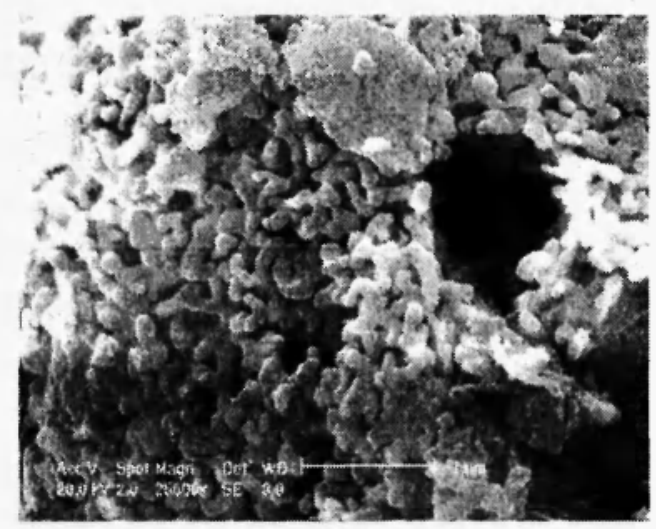

Calcination

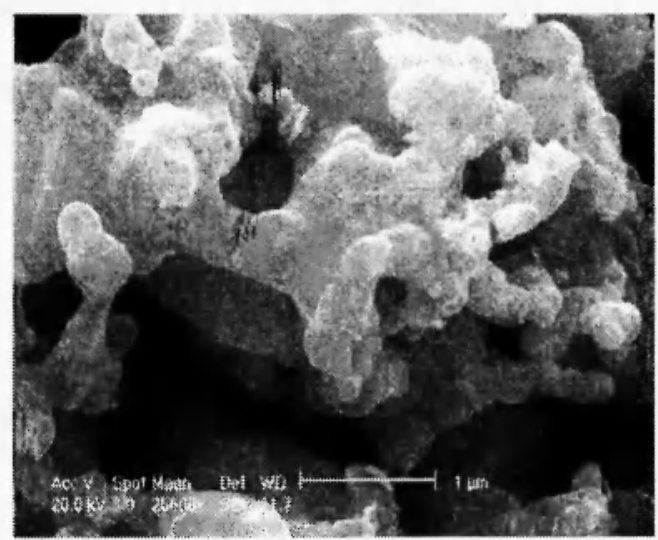

Melting observed $\left(900^{\circ} \mathrm{C}\right)$

Fig. 7: Environmental scanning electron micrographs for sintered sediments at different temperatures for $3 \mathrm{hrs}$. 


\section{CONCLUSION}

The study presented was focused on the understanding of the evolution of physicochemical properties of the dredged sediment treated with phosphoric acid during the calcination from room temperature to $1000^{\circ} \mathrm{C}$. The understanding of the evolution of these properties is of importance for the beneficial use of these materials in various fields. The characterization performed was followed by the investigation of the behaviour of heavy metals and the organic compounds during the calcination. The distribution of heavy metals between the solid and the gas phase were studied versus the calcination temperature. The result obtained showed that the majority of heavy metals are stabilized in the solid. This result is confirmed by the leaching tests. It is observed that the degradation of the organic compounds is effective at $400^{\circ} \mathrm{C}$.

One of the effects of the calcination observed is the increase of the surface area up to $400^{\circ} \mathrm{C}$ followed by a significant reduction accompanied by the particle size growth. Increase in surface area is attributed to the formation of pores due to the decomposition of organics. The evolution of properties is caused by the thermal sintering explained by the formation of necks and grain boundaries. The results presented also showed that the higher the temperature, the stronger the sintering process leading to the surface area reduction and the particle size growth.

\section{ACKNOWLEDGMENTS}

The authors wish to express their gratitude to Solvay S.A for providing samples and for the financial support to this work.

\section{REFERENCE}

1. J.R Miller and K. Hadson-Edwards: Science of Total Environment, 30, 189-209(2004).

2. L. Lei, A.P. Khodadoust, M.T. Suidan and H.H. Tabak: Water Research, 39, 349-361 (2005).

3. R. Rausa and G. Mascolo: Journal of Analytical and Applied Pyrolysis, 49, 425-445 (1999) .

4. I.-H Lee, Y-J Wang and J-M Chern: Journal of Hazardous Materials, 123, 112-119 (2005).

5. F. Marot: $B R G M$, Paris (1998), p. 330.

6. R. Derie, G. Depelsenaire and A. Nzihou, Procédé d'inertage de boue / Sludge treatment method, SOLVAY, FR2845983 \& WO2004035490, 23/04/2004.

7. S. Kribi; Decomposition of the organic matter and stabilization of heavy metals in the dredged sediments, PhD thesis, INSA Lyon (2005), p.220.

8. AFNOR Standard: Quality of grounds (1999), p.250.

9. Z. Hu, R. Navarro, N. Nomur, H. Kong, S. Wijesekara and M. Matsumura: Environmental Sciences, 1, 12-18 (2007).

10. A. Nzihou, B. Adhikari and R. Pfeffer: Ind. Eng. Chem. Res., 44, 1787-1794 (2005).

11. P. Layvolle, A. Ito and T. Tateiohi: J Am. Ceram. Soc., 81, 1421 (1998) .

12. O .Prokopiv and I. Sevostianov: Materials Science and Engineering, 431 A, 218-227 (2006).

13. J. White: Sintering and Related Phenomena (Edited by Kuczynski G.C.), Gordon \& Breach, New York, (1967), p. 245. 